\title{
ANALYSIS OF ICT, POWER SUPPLY AND HUMAN CAPITAL DEVELOPMENT IN NIGERIA AS AN EMERGING MARKET ECONOMY
}

\author{
Anthony Orji* \\ Department of Economics, University of Nigeria, Nsukka \\ E-mail: anthony.orji@unn.edu.ng
}

\section{Jonathan E. Ogbuabor}

Department of Economics, University of Nigeria, Nsukka

E-mail: jonathan.ogbuabor@unn.edu.ng

\section{Onyinye I. Anthony-Orji}

Department of Economics, University of Nigeria, Nsukka

E-mail: onyinye.anthony-orji@unn.edu.ng

\section{Chinonso Okoro}

Department of Psychology, University of Nigeria, Nsukka

E-mail: chinonso.okoro@unn.edu.ng

\section{Daniel Osondu}

University of Nigeria, Nsukka

E-mail: osondudaniel32@gmail.com

(Received: June 2020; Accepted: August 2020; Published: October 2020)

\begin{abstract}
This paper analyzed the impact of information and communication technology (ICT) and power supply on human capital development in Nigeria as an emerging market economy. The study adopted the Classical Linear Regression Model for the empirical analysis. The result showed that ICT, power supply (proxied by electricity consumption) and population impact positively on human capital development, while infant mortality has a negative impact on human capital development in Nigeria. The impact of ICT on school enrolment suggests that technology is fast evolving and new technologies are preferred to old ones. The study, therefore, recommended that Nigeria should follow in the trend of ICT globally in harnessing her human capital endowments. In conclusion, the Nigerian
\end{abstract}

*Corresponding author: Anthony Orji. E-mail: anthony.orji@unn.edu.ng

Copyright $(0) 2020$ The Author(s). Published by VGWU Press

This is an Open Access article distributed under the terms of the Creative Commons BY 4.0 license (Creative Commons - Attribution 4.0 International - CC BY 4.0) which permits unrestricted use, distribution, and reproduction in any medium, provided the original author and source are credited. 
Orji, A., Ogbuabor, J.E., Anthony-Orji, O.I., Okoro, C., Osondu, D. (2020)

Analysis of ICT, power supply and human capital development in Nigeria as an emerging market economy

government should harness her ICT and electric power potentials and develop the human capital available to her to prevent the emigration of her human resource endowment to more resilient and promising economies.

Keywords: Information and Communication Technology, Power Supply, Human Capital

JEL Codes: D83; E24; J24; L94; L96

\section{Introduction}

The role of innovation, science and technology, as well as the power supply cannot be overemphasized and neglected in this modern era as they have aided in bringing the world together as a global village. The common argument is that information and communication technology (ICT) impacts strongly on efficiency and innovative capacity and has a geometric progressive effect on economic growth (Claudio, Carlo and Elizabeth 2010). ICT has been a frontrunner and a change agent in confronting the interests and needs of different countries as discovered since about three decades ago (Kramer, William, Beth and Katz, 2007; Orji et al, 2016; Ogbuabor, et al 2020).

Information and communication technology and power supply play active roles in every economy and every sector. A lot of people place their focus on the internet and computers when they hear the word, Information and Communication Technology, but it encompasses the processes of innovation and idea generation. Telecommunication was the earliest component of information and communication technology in Nigeria with the advent of telephone service in 1923, and the introduction of VHF radio system showed growth in information and communication technology with five automatic and a hundred and sixteen manual telephone exchange. The Post and Telegraph Department and Nigerian External Telecommunication were in charge of telecommunication management prior to 1984 when they were merged to a limited liability company known as Nigerian Telecommunications Limited (NITEL). The activities of the telecommunication services in Nigeria have contributed to some visible and impressive macroeconomic effects with respect to employment opportunities, reduced transport cost, better and speedy service delivery and higher national income. ICT has gained ground as the major driver of organization competitiveness in the business environment of today. Some of these sectors are the educational and agricultural sectors. The educational sector is the bedrock for sustainable economic growth, whereas, according to Hopestone (2013) the agricultural sector is the largest economic sector in Nigeria as well as in other African countries and it presents the best opportunity for poverty alleviation and economic growth. 
Orji, A., Ogbuabor, J.E., Anthony-Orji, O.I., Okoro, C., Osondu, D. (2020)

Analysis of ICT, power supply and human capital development in Nigeria as an emerging market economy

The industrial revolution was centered on technological advancement in Europe and America in the late 90s. ICT contributed significantly to capital services growth in the United States and Canada. At the beginning of the $21^{\text {st }}$ century, the Nigerian government wanted a more efficient service; hence the information and communication technology subsector was privatized and deregulated. This policy led to the introduction of the National Telecommunication Policy in 2000 which focused on expanding the telecommunication services (Ndukwe, 2005). The government had the mission of incorporating ICT into education so as to create jobs and wealth, ensure competitiveness and reduce poverty. This requires enhancing ICT engineers, technicians, scientists, designers, software developers and all ICT operators and these will entitle the country some foreign exchange. The executive board of the United Nations Development Programme and United Nations Population Fund is strongly in agreement and argued for ICT as a priority area for development (UNDP, 2001). This was also confirmed in Mozambique by the UNDP as a tool for human development (UNDP, 2008).

In line with global best practices, Nigeria prepares her annual budget where a fraction is allotted to the power sector - the heart of industrialization. Prior to the introduction of electricity in Nigeria, Nigerians were using the natural light - fire in crude appliances such as lanterns, fire torches and many others. After the first power plant was installed in Lagos in 1896 (Road to Gencos and Discos, 2014), with time, it circulated to other parts of the country and has ever since been useful in various ways such as heating, lighting, cooling, operation of electronic gadgets, and many other numerous benefits; hence it has become an integral part of economic growth.

Unlike every other input into the production process, power has to be extracted and made available in a form ready for consumption and hence, must be in a way, manufactured (Generating Electricity, 2018). Power can be extracted from either the sun, water, air, biodegradable materials, coal gas or the recent biogas, nuclear power, etc. Over forty years ago, Nigeria's source of power has varied from the oilfired, gas-fired, coal-fired station, hydroelectric power stations with gas-fired systems and hydroelectric power systems taking the lead (Ajumogobia and Okeke, 2015). The power sector in the Nigerian economy had existed for many years, metamorphosing from one regulation to another. It had been a monopoly ever since belonging to the state. Prior to the 2005 energy sector reform, the state was in charge of the generation, transmission and distribution of power. After the 2005 liberalization, the power sector transited to a large privately-owned unbundle network. The different segment of the electricity business was separated and made the power sector a competitive market.

Nigeria, with over a hundred and ninety million persons, provides about 4,000 megawatts of electricity. However, South Africa has an installed capacity of about 
Orji, A., Ogbuabor, J.E., Anthony-Orji, O.I., Okoro, C., Osondu, D. (2020)

Analysis of ICT, power supply and human capital development in Nigeria as an emerging market economy

49,555 megawatts for about fifty-six million people (USAID, 2018). With this gap, the business environment of Nigeria is in shambles. High per capita energy consumption countries are seen as more developed than countries with low per capita energy consumption. Power is the pillar of wealth creation, the nucleus of industrialization.

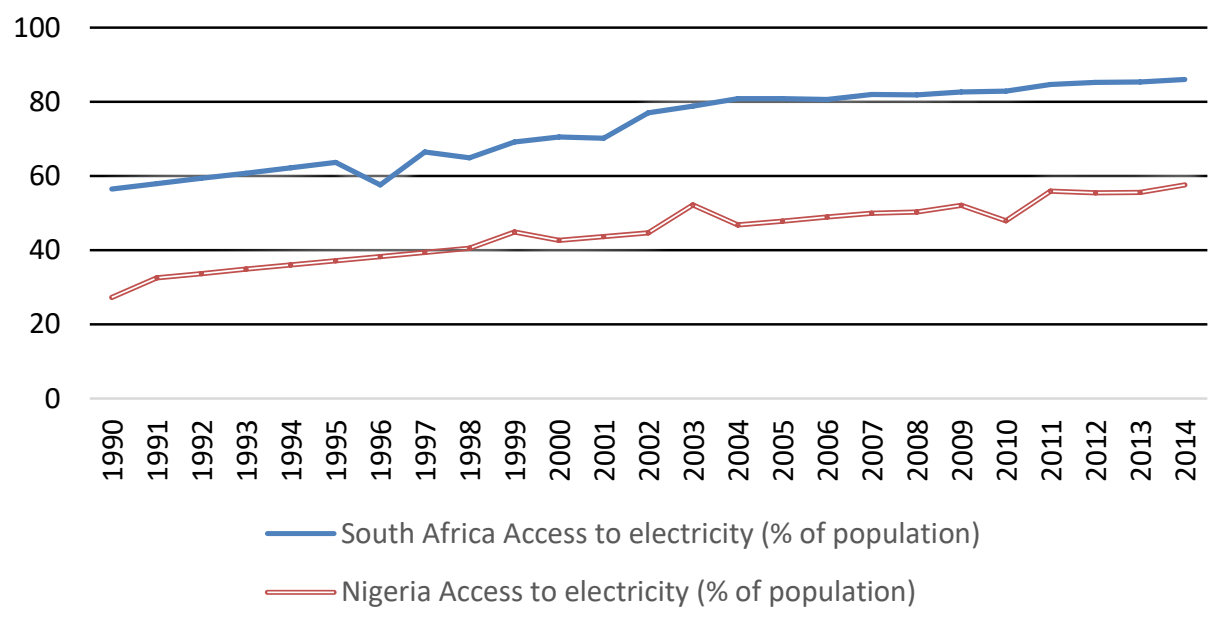

Figure 1 Graph comparing the percentage of South African and Nigerian Population that have access to electricity

Source: World Development Indicators (2016)

The graph comparing the percentage of South African and Nigerian population that have access to electricity as plotted in figure 1 denotes a steady consistent increase in both countries' population access to electricity. The upright line is in percentage, not more than 100, while the horizontal line denotes the corresponding years. The diagram above reveals that South African and Nigerian population access to electricity from 1990 to 2014 is remarkably growing. However, more percentage of the South African population has access to electricity than the Nigerian population. Noticeable in Nigeria trend, there were positive outliers in 1999 and 2003 which coincided with the nationwide election. This in essence means that either electricity availability in those years was a campaign strategy or any there were other macroeconomic reasons. However, there was a negative outlier in 2010 which tallied with the heat of insurgency and terrorist attacks majorly from the Boko Haram group. Sadly, the positive trend in electricity accessibility has not changed into significant growth in the economy, as Nigeria is ranked in the category of low human development and is placed at 152 out of 188 nations (UNDP, 2016).

58 Sciendo Studia Universitatis "Vasile Goldis" Arad. Economics Series Vol 30 Issue 4/2020 ISSN: 1584-2339; (online) ISSN: $2285-3065$

Web: publicatii.uvvg.ro/index.php/studiaeconomia. Pages $55-68$ 
Orji, A., Ogbuabor, J.E., Anthony-Orji, O.I., Okoro, C., Osondu, D. (2020)

Analysis of ICT, power supply and human capital development in Nigeria as an emerging market economy

The role of power supply and ICT on human capital development and economic growth has been an issue of much consideration to various scholars. A lot of people in Nigeria are still living in abject poverty. In the last UN official 2009-2010 estimate, Nigeria has above $50 \%$ of the population living below the poverty line. In addition to these, is the rickety nature of power supply and has led to the failure of many companies and a high unemployment level. One logic is that human capital boosts the productivity of business forms, industries and government. Achieving the goals of the firm, ICT influences various governments and business processes such as the ways individuals interact, work and live. The idea is, if ICT is judiciously utilized and electricity is sustainably developed, they have the potential to advance boundless opportunities, generate employment, reduce income inequality, encourage both local and foreign investments; this will thus produce a positive multiplier effect on human capital development and economic growth.

Over time, government spending on power supply has been huge, yet the condition of power supply is nothing to write home about. Nigeria cannot boast of constant power supply over a long period of time. Also, the information and communication technology is taking a lead in economic growth as it shifts the Nigerian economy to the first in Africa after it was incorporated into the calculation of national output. This entails that something is wrong, and a lot can be done.

Nigeria is rich in both human and material resources with over 160 million people from the 2006 census result, yet her economy has been creeping since her independence in 1960. Nigeria is ranked the $13^{\text {th }}$ least stable state in the world according to the Fragile States Index (Messner, 2017). Human capital has been a major point of competition in the labor force. It involves knowledge, skills and experiences an individual is equipped with. ICT holds a lot of opportunities to advance the knowledge, skills and experiences of the labor force. Bresnahan, Brynjolfssor and Hitt (2002) argue that the effects of ICT on the demand of labor will be more when it is merged with other investments. For example, the expenditure on computer training will do little or nothing if there are no corresponding investments on health, food and increasing the standard of living. The reason is that when one is not healthy he is likely to focus on how to redeem his health and not acquiring any knowledge. Only healthy ones go to school. Nigeria has been characterized by different economic, social and political problems.

That notwithstanding, Nigeria has embraced some policy reforms in the recent past and the ICT sector has experienced notable improvements. What used to be 400,000 , prior to 1999 skyrocketed to over 90.5 million mobile telephone lines in 2011. These breakthrough qualified the telecommunication market in Nigeria to be the fastest-growing in Africa (The Ministry of Communication Technology, 2012). The total population that have access to electricity increased from $27.3 \%$ in 1990 to 
Orji, A., Ogbuabor, J.E., Anthony-Orji, O.I., Okoro, C., Osondu, D. (2020)

Analysis of ICT, power supply and human capital development in Nigeria as an emerging market economy

$57.65 \%$ in 2014 and the rural population with access to electricity grew from $8.6 \%$ in 1990 to $39.3 \%$ in 2014 .

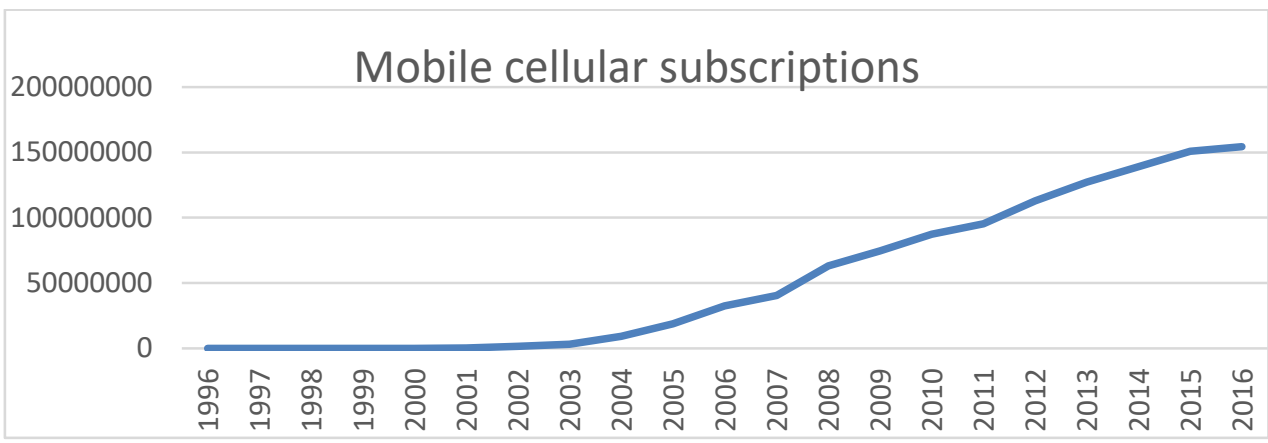

Figure 2 Graph showing the trend of mobile cellular subscriptions

Source: Researcher based on data from World Development Indicators

The graph showing trend of mobile cellular subscriptions as plotted in figure 2 denotes a steady consistent increase in the use of mobile phones and telecommunication. The upright line is the population size, while the horizontal line denotes the corresponding years. The diagram above reveals that Nigerians' use of mobile phones has drastically increased. However, this growth became visible from 2003 and has ever since been increasing. This increase in mobile subscriptions has increased access to the internet.

In spite of these developments in the power sector and in the telecom sector, the nexus between ICT, Power Sector and Human Capital Development is still not empirically clear in the Nigerian context. Some studies such as Bresnahan, Brynjolfsson \& Hitt (2002); Falk (2005); Fabiani, Schivardi \& Trento (2005); Orji, Nwosu, Anthony-Orji \& Mba, (2016); and Ejemeyovwi, Osabuohien and Osabohien (2018) have been conducted independently on issues relating to ICT across different economies but none has focused on the issues raised in this paper.

Against this background, this paper empirically examines the impact of ICT and Power Supply on Human Capital Development in Nigeria. This is the focus and value addition of this paper. The rest of the paper is structured as follows; Section 2 dwells on the review of literature, while section 3 is on the methodology. The results are presented and discussed in section 4 , while section 5 concludes the study and makes some vital policy recommendations.

\section{Literature Review}

There are a plethora of studies in the literature that have investigated the role of ICT and power supply on different sectors of the economy. However, there is a

60 S sciendo Studia Universitatis "Vasile Goldis" Arad. Economics Series Vol 30 Issue 4/2020 ISSN: 1584-2339; (online) ISSN: 2285 - 3065

Web: publicatii.uvvg.ro/index.php/studiaeconomia. Pages $55-68$ 
Orji, A., Ogbuabor, J.E., Anthony-Orji, O.I., Okoro, C., Osondu, D. (2020)

Analysis of ICT, power supply and human capital development in Nigeria as an emerging market economy

yawning gap in the literature on the empirical nexus among ICT, power supply and human capital development .in Nigeria For example, Black and Lynch (2002) used the augmented Cobb-Douglas production function to explore the impact of workplace practices and ICT on productivity in the US over the periods of 19871993. The result of his research revealed a positive impact of information and communication technology on human capital development. ICT had more significant impact than traditional production tools. In another study, Bresnahau, Ijsson and Hitt (2002) carried out research on innovative skill and labor demand in the United States. Their result showed that there exists a relationship between innovative skill and labor demand. With the use of detailed firm-level data, they concluded that when information-technology is mixed with organizational investments, it will yield a greater impact of information technology on labor demand. This is to say, the more the ICT skills one acquires, the more the chances of being employed. Hempell (2003) conducted a study to ascertain the correlation between ICT investments and training programs by firms in Germany for the periods of 1994 to 1998. Using SYS-GMM, the study revealed that training complements ICT and this combination is the most productive. Hampell also carried out a study in 2005 on the German economy for the period 1994 to 1999 to examine the impact of ICT on productivity. The result, using SYS-GMM analysis proved that there is a significant relationship between ICT and productivity.

Ceccobelli and Mancuso (2012) studied the economy of 14 OECD countries for the period 1995 to 2005 using a non-parametric (bootstrap) approach. Their aim was to uncover the impact of ICT on labor productivity growth and affirms that ICT contributes positively to labor productivity and also, that ICT is a general-purpose technology. Mary and Catherine (2003) indicated a positive relationship between ICT skilled labor and labor quality in their study on the growth of ICT and industry performance of US manufacturing sectors from 1988 to 2000. Also, the study by Moshiri, (2016) explored information and communication technology and its spillovers' impact on productivity in Canada that included 10 provinces and industries for the period 1990-2008. The study found that there was a substantial significant impact of ICT on labor productivity. Also, the study argued that services and manufacturing industries have benefited more than primary sector industries from ICT investment.

Aboal and Tacsir (2015) analyzed information and communication technology investment determinants and how productivity and innovation is influenced by ICT in the Uruguayan economy. The result revealed that the more ICT investment the less the relative price of production. Also, there is the existence of a positive relationship with ICT and service productivity. They argue that if there is no ICT investment, productivity will suffer a lower yield because of the high cost of production. 
Orji, A., Ogbuabor, J.E., Anthony-Orji, O.I., Okoro, C., Osondu, D. (2020)

Analysis of ICT, power supply and human capital development in Nigeria as an emerging market economy

To understand the situation in small and medium scale enterprises, Torrent-Sellens, Ficapal-Cusi, Boada-Grau and Vigil-Colet (2016) study 500 Jourism Catalonia, Spain small and medium scale enterprises to uncover the perceived productivity of ICT on small and medium scale enterprises. The result explored a small and medium scale enterprises' co-innovation which is focused on the introduction radically innovative products and services. However, Diaz-Chao, Sainz-Gonzalez, and Torrent-Seellens (2015) accessed new labor productivity co-innovative sources in a small firm. With 464 small and medium scale enterprises subjected to observation in Spain, their result showed that small firms are not directly affected by innovation. In another study, Zhang (2015) constructed a 35-country comparative study panel of emerging and advanced countries to uncover the contribution of human capital and ICT in encouraging the advancement of producer services. The study discovered that the phase of a country's development determines the notability of human capital and ICT joint influence. In advanced countries, there is significant evidence of joint influence, however, in emerging countries, there was no significant evidence. That is, human capital and ICT influences produce services in developed countries and not in developing countries. Simplice and Sarale (2017) analyzed 49 Sub-Saharan African countries in a bid to evaluate the roles of ICT in escalating inclusive human development for a period of 12 years in this 21 st century, from 2000 to 2012. They based their study on instrumental variable and Tobit regressions so as to elucidate the simultaneous effect and restricted scope in human development. The investigation was disintegrated into the rudimentary features that human development is established on which includes, legal origins, income levels, political stability, and resourcewealth and religious dominations. The findings among all include that strategies intended to improve information and communication technology (internet, mobile phone, telephone) infiltration will elevate inclusive development to achieve the SDGs. Also, the level of positive sensibility of comprehensive development in ICT differs across basic features of ICT dynamics and human development.

Summarily, among all the papers reviewed, none was specifically focused on the impact of power supply and ICT on human capital in Nigeria. This is the gap this current study fills.

\section{Methodology and empirical data}

To express the objective of this study, we specify a regression model on the impact of power supply and ICT on human capital development in Nigeria as:

$\mathrm{SCHE}_{\mathrm{t}}=\Upsilon_{\mathrm{o}}+\Upsilon_{1} \mathrm{FTS}_{\mathrm{t}}+\Upsilon_{2} \mathrm{EPC}_{\mathrm{t}}+\Upsilon_{3} \mathrm{INFD}_{\mathrm{t}}+\Upsilon_{4} \mathrm{POPNG}_{\mathrm{t}}+\mu$

Where SCHE is the variable for school enrolment and it is used to proxy human capital development. FTS is telephone subscriptions representing the number of active phone line users. EPC is the variable 
Orji, A., Ogbuabor, J.E., Anthony-Orji, O.I., Okoro, C., Osondu, D. (2020)

Analysis of ICT, power supply and human capital development in Nigeria as an emerging market economy

for electricity consumption. This is used by the nation to power appliances and machines such as medical lab machines and computers. INFD represents infant mortality or the number of infant deaths. Infant deaths make up the number of children that did not live to celebrate any birthday. POPNG is population growth and shows is the changes in the number of people in Nigeria over time. $\mu=$ error term; $\alpha_{0}=$ Intercept; $\alpha_{1}, \alpha_{2}, \alpha_{3}, \alpha_{4}, \alpha_{5}=$ Parameters $; t=$ time period from $1981-2016$

\section{Results and findings}

\subsection{Stationarity / Unit Root Test}

To avoid the problem of nonsensical analysis which has no economic meaning, this result presented below is key. The study utilizes the Augmented Dickey Fuller (ADF) test to check for stationarity in the model.

Table 1 Stationarity Test Result for the First Model

\begin{tabular}{|c|c|c|c|c|c|c|c|}
\hline \multirow[b]{2}{*}{ Variables } & \multicolumn{2}{|c|}{ Level Form } & & \multicolumn{2}{|c|}{ First Difference } & & \multirow[b]{2}{*}{$\begin{array}{c}\text { Order of } \\
\text { Integration }\end{array}$} \\
\hline & $\begin{array}{c}\text { ADF Test } \\
\text { Statistic }\end{array}$ & $\begin{array}{c}\text { ADF } \\
\text { Mackinnon } \\
\text { Critical Value } \\
\text { at } \alpha=0.05\end{array}$ & & $\begin{array}{c}\text { ADF Test } \\
\text { Statistic }\end{array}$ & $\begin{array}{c}\text { ADF } \\
\text { Mackinnon } \\
\text { Critical Value } \\
\text { at } \alpha=0.05 \\
\end{array}$ & & \\
\hline SCHE & -2.845137 & -3.544284 & NS & -6.333376 & -3.548490 & $S$ & $\mathrm{I}(1)$ \\
\hline EPC & -2.760222 & -3.544284 & NS & -7.626345 & -3.548490 & S & $\mathrm{I}(1)$ \\
\hline FTS & -3.549580 & -3.562882 & NS & -3.882155 & -3.603202 & S & $\mathrm{I}(1)$ \\
\hline INFD & -4.655832 & -3.552973 & $\mathrm{~S}$ & & & & $\mathrm{I}(0)$ \\
\hline POPNG & -4.228165 & -3.587527 & $\mathrm{~S}$ & & & & $\mathrm{I}(0)$ \\
\hline
\end{tabular}

*Where S and NS denotes stationary and non-stationary respectively

From the table above, variables such as infant mortality and population growth rate are stationary at level form while, school enrolment, electricity consumption and telephone subscriptions became stationary after the first difference. Thus, they are integrated of order one i.e I (1).

\subsection{Cointegration Test}

Table 2 Result of the Cointegration Test

\begin{tabular}{lll}
\hline & ADF Test Statistic & ADF Critical Value at $\alpha=0.05$ \\
\hline Residuals & -5.616727 & -3.544284 \\
\hline
\end{tabular}

In line with the result of the cointegration test above the value of ADF test statistic $(-5.616727)$ is greater than the value of the ADF 5\% critical value $(-3.544284)$ in an absolute term at level form, thus, we reject the null hypothesis and conclude that the variables are not cointegrated. In essence, among the variables, there is a longrun equilibrium relationship. 
Orji, A., Ogbuabor, J.E., Anthony-Orji, O.I., Okoro, C., Osondu, D. (2020)

Analysis of ICT, power supply and human capital development in Nigeria as an emerging market economy

\subsection{Regression Analysis}

Table 3 Regression Result for model (1)

\begin{tabular}{crrrr} 
& & & \multicolumn{2}{c}{ Dependent Variable: SCHE } \\
\hline Variables & Coefficients & Standard Error & T-Value & P-Value \\
\hline Constant & -10.56882 & 1.581735 & -6.681793 & 0.0000 \\
LOG(EPC) & 0.139447 & 0.022637 & 6.160108 & 0.0000 \\
LOG(FTS) & 0.267449 & 0.067902 & 3.938775 & 0.0004 \\
LOG(INFD) & -0.104325 & 0.224549 & -0.464600 & 0.6455 \\
POPNG & 0.624963 & 0.121543 & 5.141887 & 0.0000 \\
\hline $\mathrm{R}^{2}=0.850743$ & \multicolumn{2}{c}{ F-Stat $=44.17403$} & \multicolumn{2}{c}{ Durbin-Watson Stat $=$} \\
\hline$\overline{\mathrm{R}}^{2}=0.831485$ & \multicolumn{2}{c}{ Prob. of F-Stat $=0.000000$} & \multicolumn{2}{c}{1.950888} \\
\hline
\end{tabular}

\section{Discussions}

Our objective here is to determine if the parameters estimated conform to the expected sign and magnitude in line with existing theories.

Electric power consumption is positively related to school enrolment. The slope of electric power consumption (0.139447) shows that in the presence of as one percent more $\mathrm{kWh}$ per capita is consumed, human capital development proxied by school enrolment is approximately increased by $0.14 \%$ ceteris paribus. This result conforms to the a priori expectation. As more people are enrolled in school, the gadgets and machines that helps learning is accumulated leading to more demand of electricity. This increase in electricity consumption as a result of more learning gadgets will make learning more interesting and human capital is greatly developed. The slope of telephone subscription (0.267449) shows that more telephone subscription is desirable. A percentage increase in telephone subscriptions will on average, increase human capital by approximately 0.27 percent. This conforms to a priori expectation and in accordance with the result of Waverman, Meschi and Fuss (2005) who found that telecoms have a positive impact on economic growth in developing countries. This in essence means that ICT impacts positively on human capital development proxied by school enrolment. This result further reveals that ICT is needed in every sector of the economy, thus, as more gadgets are employed into the economy, the production process is easy and fast leading to greater output which signals a positive growth in the economy.

The number of infant deaths from the above result impact negatively on school enrolment. The slope value $(-0.104325)$ of INFD means that ceteris paribus a percentage increase in infant death will decrease school enrolment by approximately $0.10 \%$. This value corresponds to theoretical expectations. Generally, resources in relation to wants are limited leading to the competition of

64 Sciendo Studia Universitatis "Vasile Goldis" Arad. Economics Series Vol 30 Issue 4/2020 ISSN: 1584-2339; (online) ISSN: $2285-3065$

Web: publicatii.uvvg.ro/index.php/studiaeconomia. Pages $55-68$ 
Orji, A., Ogbuabor, J.E., Anthony-Orji, O.I., Okoro, C., Osondu, D. (2020)

Analysis of ICT, power supply and human capital development in Nigeria as an emerging market economy

wants. When the number of infants decreases through high mortality, it also reduces the number of children that can be enrolled in school, thereby reducing the number of human capital that would have been built or developed. Finally, population growth has a positive slope, which reveals a positive relationship with school enrolment. With a slope of 0.624963 , a percentage increase in the population will lead to approximately 0.62 percent increase in school enrolment leaving other things constant. The positive sign of the slope of population growth from this result is in line with a priori theories. This slope posits that as population increases there will be more people in the country, hence, more people will be available to be enrolled in school. Because of the growth in the population, more human capital will be developed. Interestingly, the regression results have $\mathrm{R}^{2}$ of 0.850743 and $\bar{R}^{2}$ of 0.831485 which means about $85 \%$ and $83 \%$ variations in school enrolment is explained by electric power consumption, fixed telephone subscriptions, number of infant death and population growth respectively.

\section{Conclusions, further directions of research and policy recommendations}

The purpose of this study is to unravel the impact of power supply and ICT on human capital development from 1981 to 2016. To establish this aim, the researchers utilized an econometric methodology as a functional tool for validating the stated hypothesis and answering the posed questions. The Ordinary Least Squares method of analysis was adopted. The OLS is analytically simple and easy to understand. This study found a positive long-run relationship between electric power consumption (EPC), ICT and school enrolment (SCHE) which is our proxy for human capital development. This conforms to a priori expectation and in accordance with the result of Waverman, Meschi and Fuss (2005) who found that telecoms have a positive impact on economic growth in developing countries. On the other hand, the study does not agree with Orji et al. (2016) who found that ICT contributes to unemployment in Nigeria when computers take over the jobs meant for human beings. Nigeria has vast opportunities to grow her economy and develop her human capital when there are efficiency and effectiveness in the use of ICT and power. This is one of the novel findings of this paper. Future research could investigate other aspects of ICT and green energy and its implications for economic development in Nigeria.

Having seen the importance of information and communication technology and power supply in Nigeria, immediate attention is required to improve on the power supply and ICT so as to ensure real human capital development and more sustainable growth as Nigeria pushes to join the top 20 economies of the world. With regard to the findings of this study, the following recommendations are made. First, the government should look out for other sources of electric power and diversify its source of electric power. Green energy and solar energy should be 
Orji, A., Ogbuabor, J.E., Anthony-Orji, O.I., Okoro, C., Osondu, D. (2020)

Analysis of ICT, power supply and human capital development in Nigeria as an emerging market economy

radically explored and utilized to ensure that every household in Nigeria is well lighted up. The government should place more attention on renewable sources of energy which will reduce the amount of carbon emitted into the environment. Second, the government should encourage and invest in research and development which will ensure that new technologies are made available in developing human capital. Third, the government should encourage competition not only in the distribution of power but also in the generation of power. The government should adopt functional strategies that will ensure allocated funds to the power sector are used appropriately. Fourth, the government should ensure an average participant in the labor market is equipped with ICT skills; hence, the government should incorporate productive ICT training at every level of schooling. Finally, the government should encourage the use of ICT gadgets in every sector of the economy and do away with manual systems.

\section{Acknowledgments}

The authors thank the anonymous reviewers and editor for their valuable contribution.

\section{Funding}

This research received no specific grant from any funding agency in the public, commercial, or not - for - profit sectors.

\section{Author Contributions}

"Conceptualization: Anthony and Daniel; methodology: Daniel; software: Anthony and Onyinye; validation: Anthony, Jonathan, Chinonso and Onyinye; formal analysis: Anthony and Daniel; investigation: Anthon and Daniel; resources: Jonathan and Onyinye; data curation: Anthony; writing - original draft preparation: Daniel; writing - review and editing: Anthony; visualization: Onyinye; supervision: Chinonso, Jonathan and Anthony; project administration: Jonathan and Anthony".

\section{Disclosure Statement}

The authors have not any competing financial, professional, or personal interests from other parties. The authors declare no conflict of interest.

\section{References}

1. Ajumogobia \& Okeke, (2015), Nigerian Energy Sector, Legal \& Regulatory Overview (2015), Lagos

2. Asongu, S.A., SaraLe, R., (2017), Enhancing ICT for inclusive human development in Sub-Saharan Africa Technological Forecasting and Social Change, 118, pp. 44-54. doi:https://doi.org/10.1016/j.techfore.2017.01.026

66 S sciendo Studia Universitatis "Vasile Goldis" Arad. Economics Series Vol 30 Issue 4/2020 ISSN: 1584-2339; (online) ISSN: $2285-3065$

Web: publicatii.uvvg.ro/index.php/studiaeconomia. Pages $55-68$ 
Orji, A., Ogbuabor, J.E., Anthony-Orji, O.I., Okoro, C., Osondu, D. (2020)

Analysis of ICT, power supply and human capital development in Nigeria as an emerging market economy

3. Black, S.E., Lynch, L.M., (2002), How to Compete: The Impact of Workplace Practices and Information Technology on Productivity, Review of Economics and Statistics, 83(3), pp. 434-445

4. Bresnahan, T.F., Brynjolfsson, E., Hitt, L.M., (2002), Information Technology, Workplace Organization, and the Demand for Skilled Labor: Firm-Level Evidence, The Quarterly Journal of Economics, 117(1), pp. 339-376

5. Carlo, C.D., Santarelli, E., (2010), Contribution of ICT to economiic growth in Itally, Input Output Analysis

6. Diaz-Chao, A., Sainz-Gonzalez, J., Torrent-Seellens, J., (2015), ICT, Innovation, and Firm Productivity: New Evidence from Small Local Firms, Journal of Business Research, 68(7), pp. 1439-1444

7. Ejemeyovwi, J.O., Osabuohien, E.S., Osabohien, R. (2018), ICT investments, human capital development and institutions in ECOWAS, Int. J. Economics and Business Research, 15 (4), pp. 463-474

8. Fabiani, S., Schivardi, F., Trento S., (2005), ICT Adoption in Italian Manufacturing: Firm Level Evidence, Industrial and Corporate Change, 14(2), pp. 225-249

9. Falk, M., (2005), ICT-linked Firm Reorganisation and Productivity Gains, Technovation, 25(11), pp. 1229-1250

10. Falki, N., (2009), Impact of Foreign Direct Investment on Economic Growth in Pakistan, International Review of Business Research Papers, 5 (5), pp. 110-120

11. Kramer, W.J., Jenkins, B., Katz, R.S., (2007), The Role of the Information and Comunications Technology Sector in Expanding Economic Opportunity, Economic Opportunity Series

12. Mary, M.O., Catherine, R., (2003), The Growth of ICT Industry Performance Manufacturing in the US and UK Compared, Nation Institute Economic Review, 184(1), pp. 60-73

13. Messner, J.J., (2017), 2017 Fragile States Index. Fund for Peace

14. Moshiri, S., (2016), ICT Spillovers and Productivity in Canada: Provincial and Industry Analysis, Economics of Innovation and New Technology, 25(8), pp. 801820

15. Ndukwe, E.C., (2005), Opening up the market and sector reform, SATCOM 16. Ogbuabor, J.E., Eigbiremolen, G.O., Orji, A.; Manasseh, C.O., Onuigbo, F.N., (2020), ICT and Financial Inclusion in Nigeria: An Overview of Current Challenges and Policy Options, Nigerian Journal of Banking and Finance 12(1), pp. 90-96. Available at: www.njbaf.com

17. Orji, A., Nwosu, E.O., Anthony-Orji, O.I., Mba, P.N., (2016), ICT Usage and Unemployment Rate Nexus in Nigeria: An Empirical Analysis, Journal of Internet Banking and Commerce 21 (2), pp. 1-13 
Orji, A., Ogbuabor, J.E., Anthony-Orji, O.I., Okoro, C., Osondu, D. (2020)

Analysis of ICT, power supply and human capital development in Nigeria as an emerging market economy

18. Torrent-Sellens, J., Ficapal-Cusi, P., Boada-Grau, J., Vigil-Colet, A., (2016), Information and Communication Technology, Co-Innovation, and Perceived Productivity in Tourism Small and Medium Enterprises: An Exploratory Analysis, Current Issues in Tourism, 19(13), pp. 1295-1308

19. Waverman, L., Meschi, M., Fuss, M., (2005), The Impact of Telecoms on Economic Growth in Developing Countries, The Vodafone Policy Paper Series, 02 (03), pp. 10-24

20. Zhang, R., (2015), Does the Synergistic Effect Exist between ICT and Human Capital in the Development of Producer Services? - A comparative study based on the panel data of emerging economies and advanced, Nanjing Business Review 